\title{
Brazilian Neurology is against racism
}

\section{A Neurologia brasileira é contra o racismo}

Hélio Afonso Ghizoni TEIVE', Paulo CARAMELLI²

\author{
'Universidade Federal do Paraná, \\ Hospital de Clínicas, Department \\ of Internal Medicine, Neurology \\ Service, Curitiba PR, Brazil. \\ Universidade Federal de Minas \\ Gerais, Faculdade de Medicina, \\ Department of Internal Medicine, \\ Belo Horizonte MG, Brazil. \\ Hélio Afonso Ghizoni TEIVE \\ (D) https://orcid.org/0000-0003- \\ 2305-1073; Paulo CARAMELLI \\ (iD) https://orcid.org/0000-0002- \\ 4786-6990 \\ Correspondence: Hélio Afonso \\ Ghizoni Teive; E-mail: hagteive@ \\ mps.com.br \\ Conflict of interest: There is no \\ conflict of interests to declare. \\ Received on June 20, 2020 \\ Received in its final form on \\ June 20, 2020 \\ Accepted on June 22, 2020
}

(c) BY

$\mathrm{I}$ $\mathrm{n}$ the midst of the tragedy of the worldwide COVID-19 pandemic, whose effects have been particularly strongly felt in Brazil, the last weeks have seen yet another social upheaval following the barbaric murder of a young black man by a white police officer in the USA. Reactions to this shocking murder spread quickly across the world and led to widespread protests worldwide and in Brazil.

The president of the American Academy of Neurology (AAN) and other members of the board, including the new chair of the AAN Equity, Diversity, and Inclusion Joint Coordinating Council, immediately published an official statement addressed to all AAN's members'. The document, namely the Position Statement on Systemic Racism and Inequities in Society, strongly condemns and deplores racism, which is still deeply ingrained in American society. The creation of an AAN special commission to recommend specific actions was approved with the fundamental objective of reinforcing support for actions aimed at objectively establishing equity, diversity, and inclusion ${ }^{1}$.

In Brazil, the president and board of directors of the Brazilian Academy of Neurology (Academia Brasileira de Neurologia - ABN) adopted a similar attitude and immediately issued a statement condemning racism and its various expressions ${ }^{2}$. Arquivos de Neuro-Psiquiatria (ANP), the official journal of the ABN, fully supports the views expressed by ABN's board and deliberative council in the statement.

There is a consensus that Brazilian neurologists should support the struggle to reverse historical racial and social inequities, which are reflected in the very small number of black neurologists in Brazil2 ${ }^{2}$. It is worth recalling that Professor Antonio Austregésilo, founder of the first school of Neurology in Brazil and first holder of the Chair of Neurology at the Faculty of Medicine of Rio de Janeiro (in 1912), which subsequently became the National Faculty of Medicine, University of Brazil, and is now known as the Faculty of Medicine, Federal University of Rio de Janeiro, was of mixed African and European origin and from a humble background in Recife, in the northeast of Brazil ${ }^{3,4}$. Another renowned figure, Professor Enjolras Vampré, considered the father of Neurology in São Paulo State, was the first holder of the Chair of Neurology at the Faculty of Medicine, University of São Paulo. Professor Vampré was also of mixed African and European origin and from northeastern Brazil (Laranjeiras, in the state of Sergipe) ${ }^{4,5}$. These two pioneering professors, who held chairs of Neurology, were considered bastions of the foremost Brazilian medical schools in Rio de Janeiro and São Paulo. Both completed internships in what were then the world's leading centers for Neurology studies and had deep African-Brazilian roots, showing the tremendous racial miscegenation that is a hallmark of Brazilian society ${ }^{3,4,5}$. On behalf of the ANP and in line with the ABN policies, we reaffirm our support for anti-racist movements and for diversity and social equality worldwide, particularly in Brazil.

\section{References}

1. Stevens JC, McClean JC, Post ME. Official AAN Position. American Academy of Neurology AANe, June, 2020.

2. Brazilian Academy of Neurology. Declaration. Brazilian Academy of Neurology, June, 2020.

3. Teive HAG, Sá D, Silveira Neto O, Silveira O, Werneck LC. Professor Antonio Austregésilo. O pioneiro da Neurologia e do estudo dos distúrbios do movimento no Brasil. Arq Neuropsiquiatr. 1999 Sept;57(3-B):898-902. https://doi.org/10.1590/ S0004-282X1999000500030
4. Gomes MM, Cavalcanti JL, Engelhardt E. French school of neurology in the 19th and first half of the 20th century, and its influence in Brazil. Arq Neuropsiquiatr. 2013 Oct;71(10):818-21. https:// doi.org/10.1590/0004-282X20130129

5. Meira AT, Bettini BG, Cardoso F, Gomes MM, Barbosa ER, Prado RCP, et al. First stages towards the establishment of Brazilian neurology faculties. Arq Neuropsiquiatr. 2019 Dec;77(12):888-95.https://doi.org/10.1590/0004$282 \times 20190147$ 